\title{
電気防食と被覆防食の現状と将来
}

\author{
篠 田吉 央* \\ * 株式会社ナカボーテック 技術研究所
}

1.は じめに

情報技術や新素材の技術は目覚ましく進歩している一 方で，電気防食や被覆防食の基本的な技術は 10 年前, いや 30 年前と比べても，あまり代わり映えがないよう に思える。これらの技術はそれだけ伝統と信頼のある技 術とも言える ${ }^{1)}$ 。ただし, 設計手法や防食評価の考察な どの研究開発は数多く実施されてきた。その中でも鉄筋 コンクリート構造物は新たな電気防食の対象として近年 着実に実績をあげてきている，従来は，海洋環境に建設 された鋼構造物, 土壤中に埋設された鋼製の配管やタン クの外面, 海水や淡水に接する熱交換器や除塵装置, 配 管内面，水門などに使用される主に鋼材が防食対象であ った。本稿では，防食対象の環境別に電気防食と被覆防 食の現状と将来について簡単に整理してみる.

\section{2. 海洋環境の防食}

海水は電気抵抗率が低いため, 電気防食が最も得意と する分野である、鋼管杭式の棚式栈橋や鋼矢板岸壁など が防食対象となる。ただし，干満帯や飛沫帯に暴露され る鋼材は電気防食単独では防食効果が十分でないため, 重防食（被覆防食）と呼ばれる厚い被覆層で環境遮断し て防食される。

\section{1 被覆防食}

被覆防食には無機・有機・複合被覆などあり, 防食専 業者は既設構造物の後施工としてペトロラタムペースト やテープを鋼材に直接塗布または巻き付け, FRP カバー で保護する工法を主に実施している。ペトラタムは腐食 抑制剤やワセリン，コンパウンド等を含んでおり優れた 防食効果を示し，30 年以上の実績がある ${ }^{2)}$. 図 1 は 2003 〜2006 年に山口県大島大橋の大口径 ( $\phi 3500 \mathrm{~mm})$ の 多柱基礎鋼管杭に適用した事例である。大島大橋では潮 流の速いなか, 様々な工夫を考えて海中部も潜水作業に より電気防食を施工している。

一方，ミルメーカーでは予め鋼材にウレタン樹脂や耐 海水性ステンレス鋼が被覆された材料の適用なども工夫 もされ, 後者は羽田 D 滑走路ジャケット栈橋部の大気か ら干満帯に大規模に採用されている。採用に当たっては 海中電気防食への影響も考慮されている3 .

なお, ペトロラタム工法の保護カバー材は, FRP の代 わりにチタン材やスーパー二相ステンレス材 ${ }^{4}$ を使用す

* † 362-0052 上尾氏中新井 417-16（417-16, Nakaarai, Ageo, 362-0052 Japan)
る動きもある。美観や軽量化，耐久性向上を狙うもので ある。防食層も新材料として特殊ウレタン樹脂 ${ }^{5}$ が実用 化され，促進試験ではペトロラタムと同等以上の防食性 能を示した. ペトロラタムでは施工が難しい環境などで の適用が期待されている.

また，防食効果や防食層の健全性を判定するためのモ ニタリング手法も開発が急がれている．防食層に金属板 を入れ防食対象鋼材とのガルバニック電流などを計測す ることにより防食性能を評価する試みがある ${ }^{6)}$ 。この試 験は約 20 年間以上続けており防食性能の劣化は認めて いない. 今後開放点検を実施し評価手法を検証していく 計画がある．他に交流インピーダンス法により下地鋼板 の表面状態が重防食塗膜下腐食に及ぼす影響について検 討した例 ${ }^{7} も$ も, 評価精度向上が期待される.

\section{2 電気防食}

港湾鋼構造物の電気防食の主流はアルミニウム合金製 の流電（犠牲）陽極材であり，図 2 に示すように主に水 中溶接によって取り付けられる.急冷しながらの直流ア ーク溶接のため, 脚長・溶接長は厳密に管理され, 溶接 時の極性も陸上と逆で行われる。最近ではジャケット構 造の栈橋が多くなり, 陸上で築造されるため犠牲陽極も
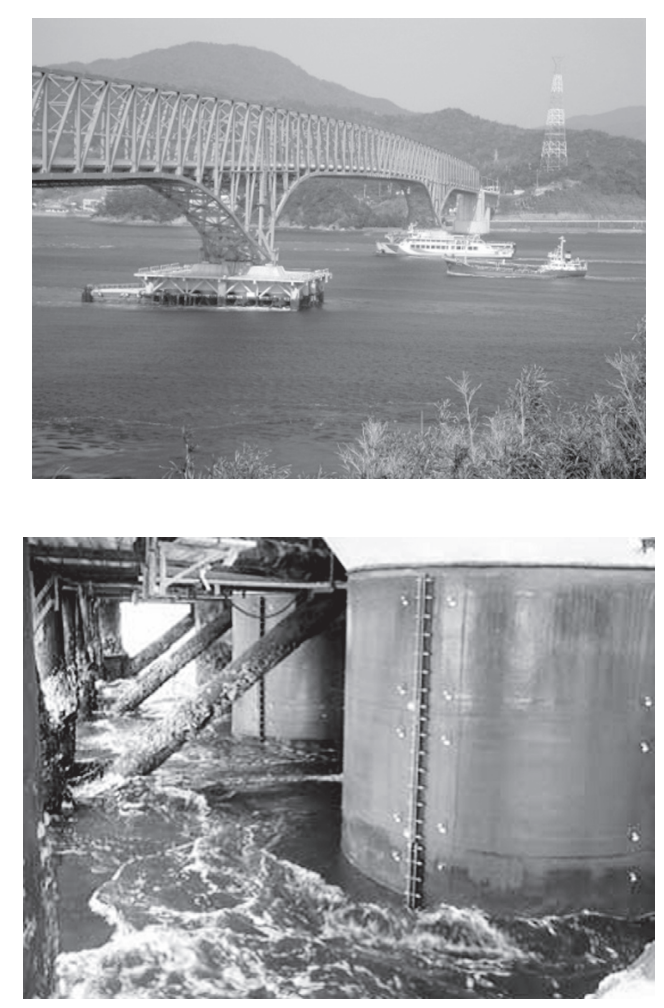

図 1 潮流により白波立つ大島大橋全景と被覆防食近景 


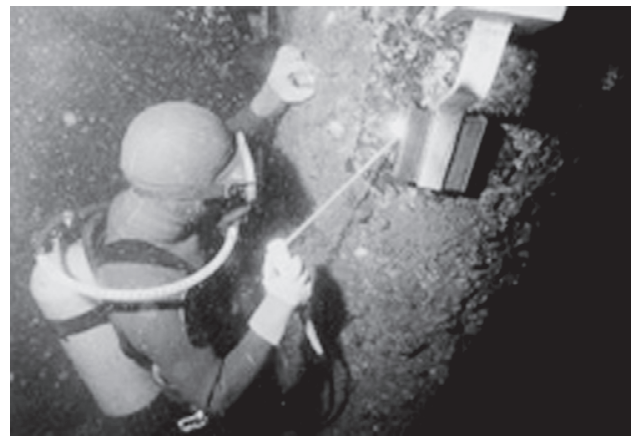

図 2 水中溶接

大気中で溶接でき, 図 3 に示す羽田空港 D 滑走路はその 例である。

羽田の陽極の配置は電位電流分布を FEM 解析などに よって設計されているが，これは数值計算ソフトの飛躍 的な発展によりパーソナルコンピューターでも解析でき るようになったためである，また，同様なジャケットで は, FEM を用いて犠牲陽極消耗に対する防食の限界を 推定している ${ }^{8}$. また，一部の鋼材電位を計測すればべ イズ推定法という逆解析手法によって犠牲陽極材の発生 電流を推定できることが立証されており興味深い9.

なお，羽田では海底土中部の鋼管杭一の電気防食効果 範囲を調查している ${ }^{10), 111}$. この鋼管杭は他の杭と絶縁さ れて抢り，テストピースを多数配置して電位電流分布を 計測し，海中部に設置したアルミニウム合金製犠牲陽極 の防食効果範囲について長期的な検討が計画されている.

犠牲陽極法の電気防食設計は, これまで陽極 1 個の発
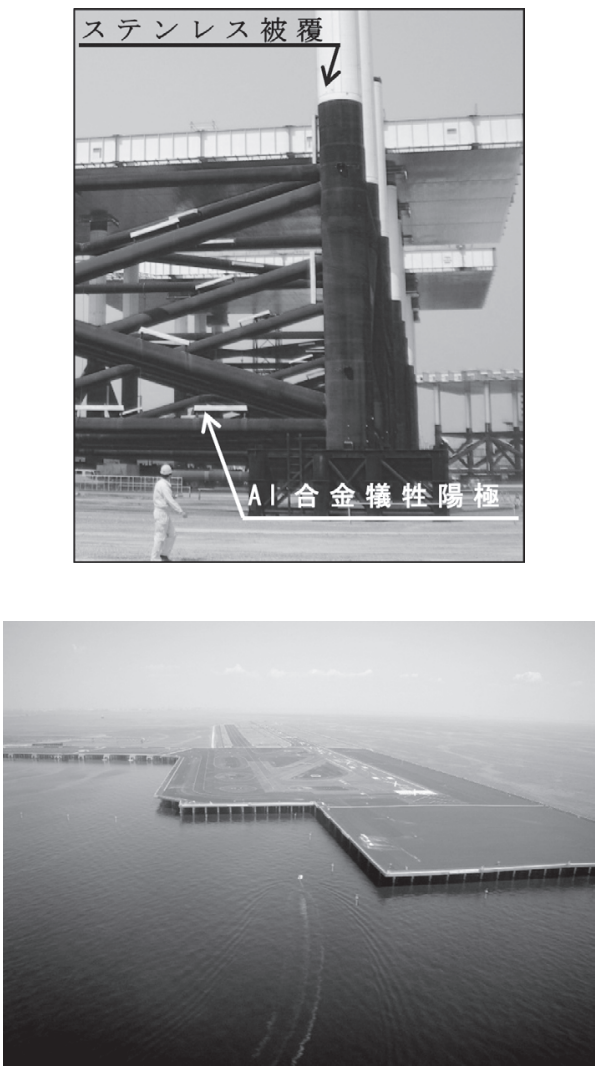

眓 3 ジャケット構造とそれを用いた羽田 D 滑走路
生電流值から全体の総取付個数を算出してきた ${ }^{12)}$. 一方 で，耐用年数から計算される陽極総質量から算出する方 法もあり両者の妥当性が検討された ${ }^{13)}$. 現在では，まず 質量設計を満足させて, 陽極 1 個当たりの発生電流が, 陽極 1 個が担う初期所要防食電流以上であればよいこと になって扬り ${ }^{14)}$, 初期と定常状態の防食電流密度を考虑 した設計と言える。しかし，海外では終期の防食電流密 度も考慮した設計が主流で，国内でも当該設計を検討し た例 ${ }^{15}$ があり，更なる設計高度化が期待される。

犠牲陽極の更新に関しても研究成果が報告されてい る. 実際の鋼材電位 $\left(E_{\mathrm{c}}\right)$ と防食電流密度 $\left(i_{\mathrm{c}}\right)$, 陽極電 位 $\left(E_{\mathrm{a}}\right)$ の関係 $\left(E_{\mathrm{c}}=R \cdot i_{\mathrm{c}}+E_{\mathrm{a}}, R\right.$ : 陽極接水抵抗 $)$ お よび現状の維持管理電位から更新後の防食電流密度を検 討する例が提案されている ${ }^{16)}$ 。さらに，小さな犠牲陽極 （子陽極）を海水に投下し，その発生電流を計測するこ とにより，施設本体に取り付けてある本陽極（親陽極） の発生電流を推定し, 陽極更新時期を推定しょうとする 動きもある ${ }^{17)}$.

このように儀牲陽極方式が主流の港湾分野だが，外部 電源方式も見直されることを今後期待したい。犠牲陽極 方式は更新の都度, 水中溶接が必要であるのに対し, 外 部電源ではスパナだけで陽極を更新することができる. 防爆対策などの初期投資は大きいが，火気制限のある施 設では重宝している電気防食方法である.

\section{3. 土壤中の電気防食}

土壇は高抵抗から不均質環境であるため，電流分布は 悪く鋼材は塗覆装でまず防食される。しかし，塗覆装に 欠陥があることを想定して電気防食が適用される，特に ガス管の漏洩は絶対禁物なので電気防食は必ず適用され る. その他, 上水・工水・農水・燃料配管・電気配管な どの地下埋設管外面，ガソリンスタンドの地下タンク外 面 $^{18)}$, 地上のオイルタンク底板裏面などが防食対象とな る.

ガス管や水道は身近にあるので，図 4 に示すような電 気防食用の外部電源装置を見ることができる。また図 5 に示すような太陽電池を利用した外部電源装置の採用も 早くから実用化されている。高抵抗のため外部電源方式 による電気防食が多いが，条件により犠牲陽極方式も採 用される。

埋設配管の電気防食は，どこにあるか分からない塗覆 装欠陥部に確実に防食電流が流入し防食状態にあるか評

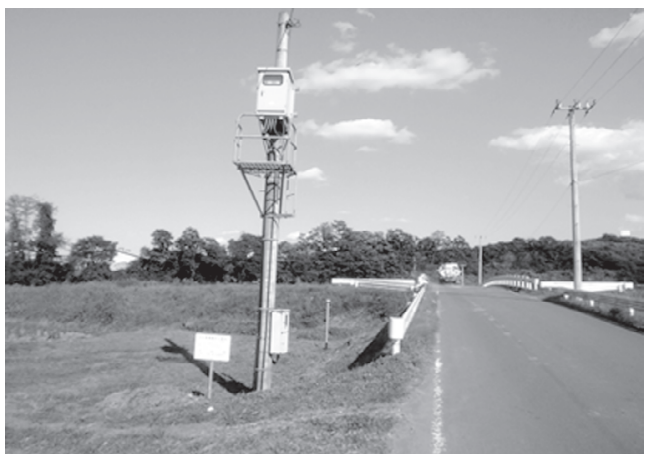

図 4 埋設配管の電気防食用柱上型外部電源装置 


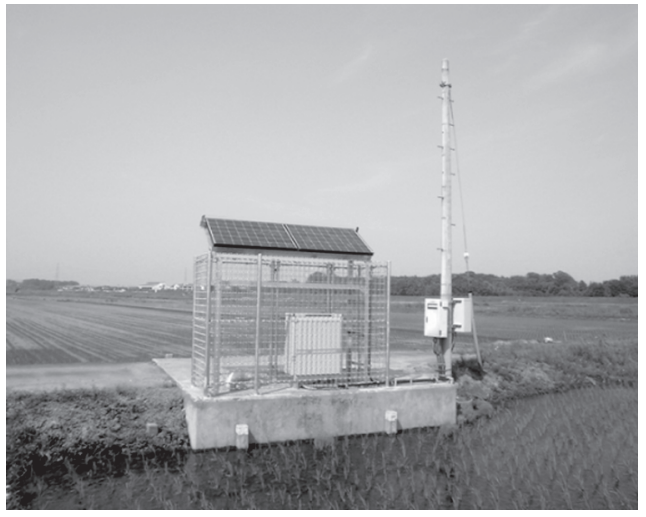

図 5 太陽電池を用いた外部電源装置

価しなければならない。通常は地表面に照合電極を設置 して埋設管の電位を計測するが，これには土壌を防食電 流が通過する際のオーム損（IR ドロップ）が誤差として 加算され，さらに欠陷直上での測定とは限らないことか ら評価が難しい。 そこで疑似欠陥（プローブ）などを最 も電流分布の悪い所に設置し，IR 補正した電位などで評 価することなどが実施されている。また，それらについ て国際基準で定めた電気防食評価法をまとめた文献 ${ }^{19)}$ が ある。

最近では，埋設管の塗覆装欠陥部に流れる電流密度を 地表面の電位差から数值解析により推定する方法 ${ }^{20)}$ が検 討されている。 また，伝送線モデルに類似した抵抗回路 網で塗覆装欠陥を有する埋設管の電気防食を模擬し, 数 学的に行列式を解くことにより電位電流分布を解析する ことも報告 ${ }^{21)}$ されている. これにより複数の埋設管が接 触する系でも比較的簡単に電位電流分布が推定できるこ とも期待される.

その他，埋設管にステンレス鋼を使用する場合の土䁃 環境に対する耐食性の評価や電気防食基準についても検 討 ${ }^{22)}$ されている.

施工面では狭い土中コンクリートピット内でも陽極が 設置できる工法が開発された。埋設管のバルブなどはピ ット内に据え付けられ，管は土中からピットを貫通す る.コンクリートと土中という異種環境を貫通するた め, 土㙵と接する管の電位は卑に，コンクリートと接す る管の電位は貴になり，土壤側の管が腐食しやすくな る、管がコンクリート中の鉄筋と接触すると腐食は加速 される。これを防ぐため従来はピット近傍を開削し電気 防食用陽極を設置していた。開発された工法は，図 6 に 示すようにピット壁面にコアを開け，十分に強度計算さ れた陽極をコアから土中へ圧入する．外部電源方式と流 電陽極方式どちらでも施工でき, 工期が短縮され工費も 安価となった。

今後も埋設配管の重要性は増加し，その敷設距離も延 びていくことから，この分野の研究開発は更に活発にな るものと期待される.

\section{4. 陸上機器設備の電気防食}

我が国では河川水の利用が制限されるため, 発電所や 化学プラント, 製鉄所など, 多量の冷却水を必要とする 施設の殆どは臨海地区に建設される．海水は冷却水に使
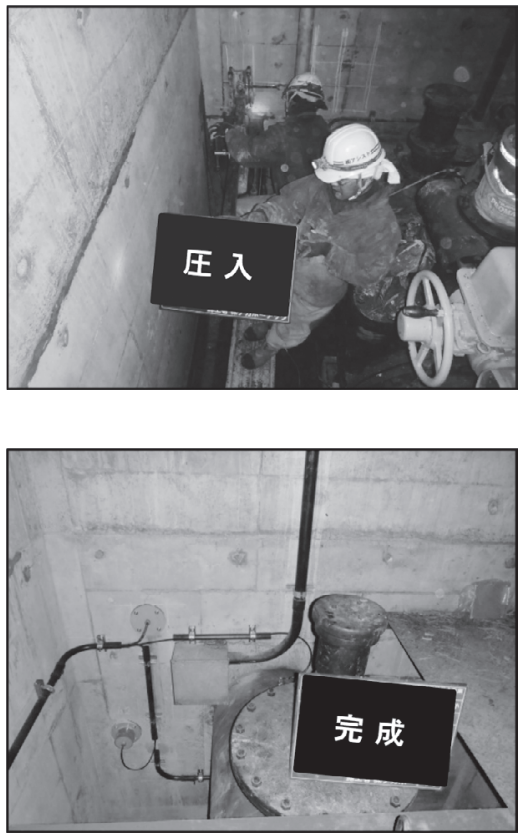

図 6 コンクリートピット内から土中に陽極を水平圧入

用しやすいからである。このため，除塵機やポンプ，配 管 (図 7), 復水器, 熱交換器（図 8) などに使用される 鋼材は海水に接しており塗装と電気防食により防食され ている ${ }^{23)}$ 。犠牲陽極材が主であるが，復水器などの大型 機器は外部電源方式で電気防食している. 複雑な形状や 流速なども考慮し, 場合によっては FEM も活用して陽 極の配置が決定されている ${ }^{24)}$.

他に, 熱交換器や復水器の伝熱管は銅合金が使用され

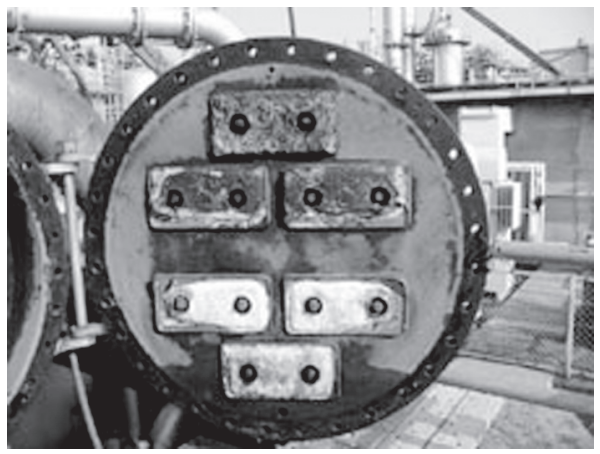

図 7 熱交換器水室内面に配置された犠牲陽極

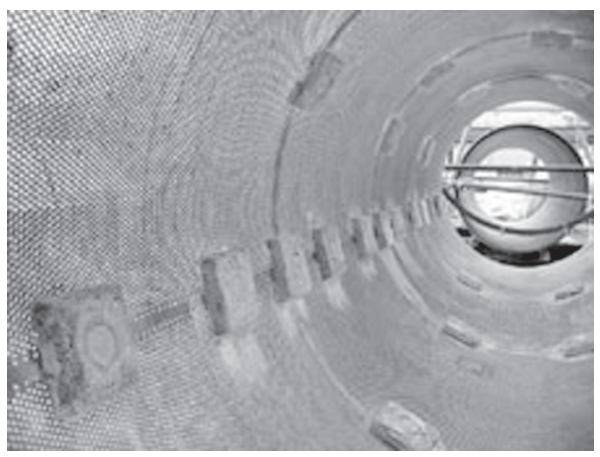

図 8 配管内面に配置された犠牲陽極 
ることもあり，鉄イオンを供給して銅管内面に鉄酸化被 膜を形成させて防食する方法もある ${ }^{25)}$. 図 9 は電解式鉄 イオン供給装置と呼ばれ, $3 \cdot 11$ 震災以降, 古い火力発電 所の再稼働と共に, 改めて活躍している.

また，河川水の有効利用や災害対策として河口付近に は大きな水門が数多くあり電気防食されている. 主な材 料は塗装鋼材であるが，止水ゴムやローラーなどはステ ンレス鋼も使用されており, 異種金属接触腐食の防止も 含めて電気防食で防食されている。環境は下流側が海 水, 上流側が淡水となり, 潮位や河川流量, 水門の稼働 状態により環境変化が大きく腐食性評価に関する研究 ${ }^{26)}$ が行われてきた。図 10 に淀川大堰の電気防食実施例を 示す．同堰ではコンクート中の鉄筋も塩害対策のため電 気防食されている.

淡水環境下での電気防食ではダムの取水設備に適用し た例 ${ }^{27)}$ がある，塗膜の劣化度を把握した上で，電位分布 を考慮し Pt めっき Ti 線状陽極による外部電源方式にて 防食されている。この線状電極は, 温水貯蔵タンクの内 面防食に多数採用された時期もあった.

最近では LNG 地下備蓄などにも電気防食は採用され ている. 図 11 は, 海底面地下深くの堅牢な岩盤をくり 抜いて LNG を水圧により封入する施設である.

電気分解を利用した技術も活用されてきている．海生 生物付着防止システムで, 触媒をコーティングしたシー 卜状の電極を熱交換器水室や管板面全体に貼り付け陽極 とし，別途設けた陰極へ電流を流すものである。シート 面は活性状態にあるので海生物の幼生が付着しにくいよ うで, 大型取水路やポンプ取水室内面のコンクリート壁 などへも実用化されつつある ${ }^{28)}$.

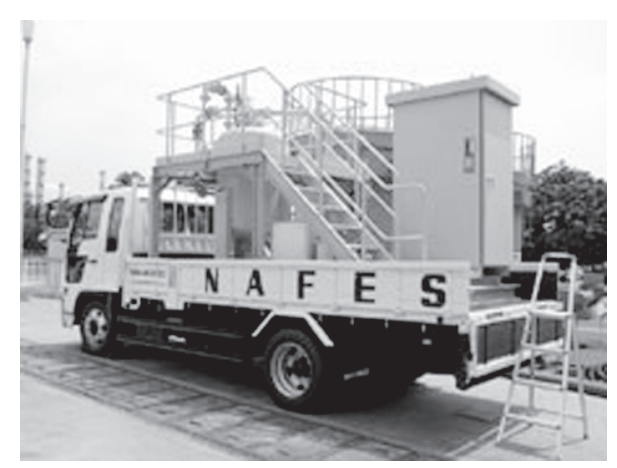

移動式

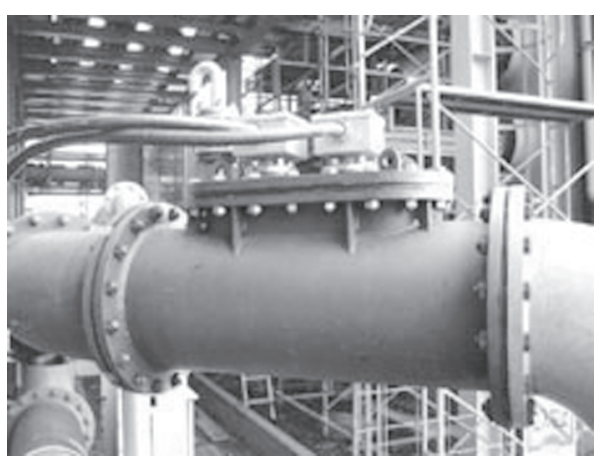

管内挿入型

図 9 電解鉄イオン供給装置

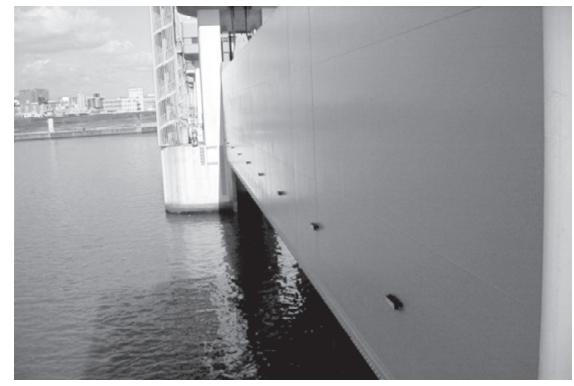

海側扉体

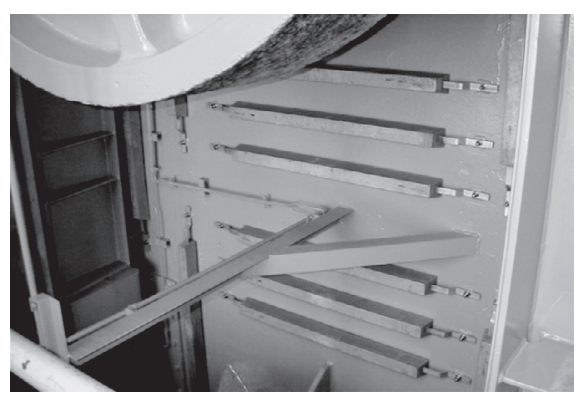

河川側屝体端部

図 10 淀川大堰の犠牲陽極による電気防食
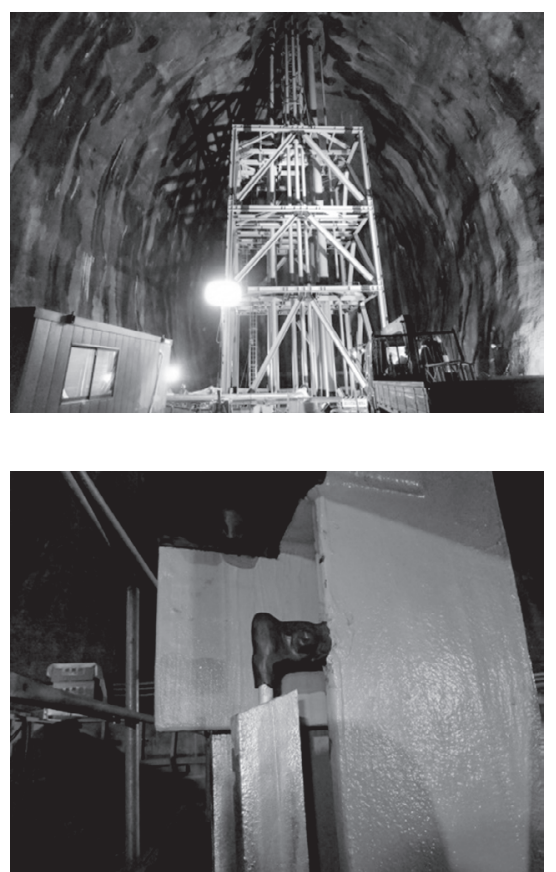

図 11 LNG 地下備蓄設備にも電気防食

\section{5. 鉄筋コンクリートの電気防食}

\section{1 コンクリートの塩害}

コンクリートは圧縮には強いが引っ張りには弱い.引 っ張り力に対抗するために鉄筋や PC 鋼材を導入し，圧 縮にも引っ張りにも強い材料となったのが鉄筋コンクリ ートである．セメントは自給自足できる数少ない資源で もあり, あらゆるインフラ設備がコンクリートを利用し て築造されていると言っても過言ではない.コンクリー 卜は概ねセメント $10 \%$ と水 $15 \%$, 砂（細骨材） $30 \%$, 
砂利（粗骨材） $40 \%$, 空気 $5 \%$ の容積比率で構成され る $^{29)}$. セメントは水和反応により硬化し $\mathrm{Ca}(\mathrm{OH})_{2}$ を多 量に含むため, pH 12 以上の高アルカリを示し，鉄筋は 不動態皮膜を形成し腐食しない.このため半永久構造物 と言われてきた。

しかし，水は硬化反応だけでなく，作業性（流動性） も向上させる役割があり, その一部は自由水としてコン クリート内部に $5 \%$ 程度留まる。 また, 空気も練り混ぜ 時に 1 〜 $2 \%$ 混入する他，薬剤を用いて凍害を抑制させ るため混入することもあり $4 \%$ 程度存在する。このよう に水と酸素は存在するので, 塩化物イオンの浸透や中性 化により鉄筋の不動態皮膜が破壊されれば腐食する可能 性がある．鉄筋は引っ張り力の働くコンクリート表層近 くに配筋されるので，こうした影響を受け易い位置にあ る。特に海からの飛来塩分や凍結防止剂による塩分浸 透，あるいは海砂使用で鉄筋が腐食する例が多く，鉄錆 の膨張圧でコンクリートにクラックや剥離, 剥落を生 じ，塩害と称される社会問題となっている ${ }^{29)}$.

\section{2 コンクリートの塩害対策と電気防食}

塩害対策は表面塗装やコンクリートを打ち替える断面 修復が主流であるが，浸透した塩分が除去しきれず，ま た既設部と補修部境界の環境変化でマクロセル腐食が起 り再劣化する例も無視できなくなった.

そこで，コンクリートに対しても電気防食が 30 年程 前に試みられた。高抵抗環境（抵抗率：約 $100 \mathrm{k} \Omega \cdot \mathrm{cm}$ ) のため電流は流れないと思われたが，試験を行うと海水

(抵抗率 : 約 $30 \Omega \cdot \mathrm{cm}$ ) の $1 / 10$ 程度の電流が流れ, 電 気防食ができることが分かった ${ }^{30)}$.

ただし，㓌極となる鉄筋はコンクリート表層近くに高 密度で配筋されるため, コンクリート表面に設置される 電気防食用陽極と近接することになる．高抵抗かつ極間 距離が短いため小面積の陽極では電流分布が悪い. よっ て，陽極もコンクリート表面に高密度で配置する必要が ある、コンクリート内部に陽極を挿入することもある が, 容積は限られており, この場合も多数の挿入孔を設 ける必要がある。

電気防食の方式としては外部電源方式と犠牲陽極方式 が両立している。国内では亜鉛板による犠牲陽極方式が 当初普及した ${ }^{31}$. . その後, 海外から貴金属酸化被膜の付 いたチタン製のラス網状の面状電極や線状電極が導入さ れた．東京都大井埠頭の棚式栈橋上部工での採用をきっ かけに, 特に線状電極は施工性の良さとコンクリート躯 体の観察もできることから，栈橋の他に橋梁でも多用さ れるようになった.ささらに共同溝 (図 12) やボックスカ ルバートなどにも普及している。

また, 外部電源方式では, 高純度チタンをアーク溶射 して塗装感覚でコンクリート表面に陽極を設置する方法 ${ }^{32}$ （図 13）や，FRPトレイに陽極と電解質を充填したも のを耐食性ビスで取り付ける方法 ${ }^{33}$ (図 14）なども普及 している.

なお，最近では，電源装置の管理が負担となる場合も あり，改めて犠牲陽極方式も見直され，亜鉛防食板方式 が清水港で大規模に採用された ${ }^{34}$ (図 15)。また亜鉛に代 わる材質としてアルミニウム系犠牲陽極板 ${ }^{35}$, 36) (図 16) も開発され，徐々に普及してきている，犠牲陽極材は,

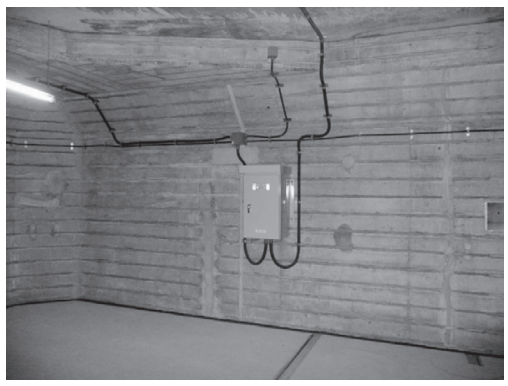

図 12 共同溝に適用した線状陽極式外部電源電気防食
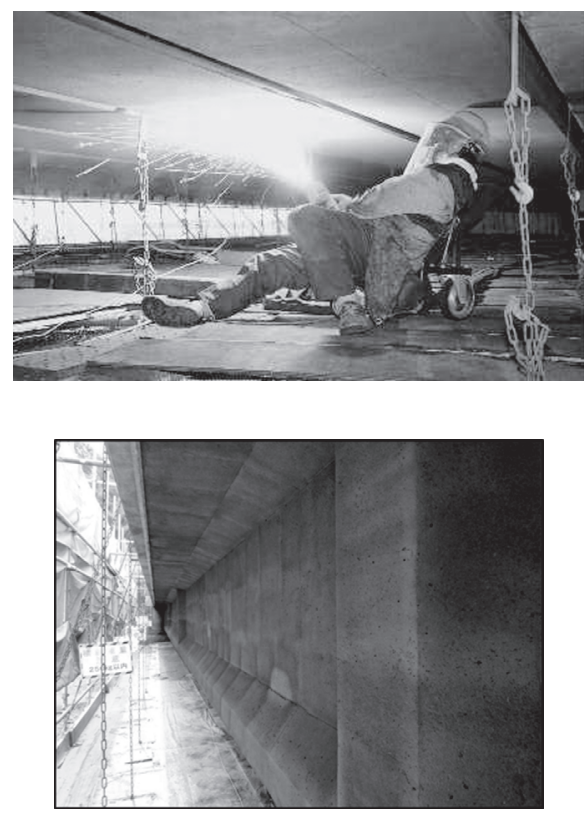

図 13 Ti 溶射によるの橋梁 PC-T 桁の電気防食

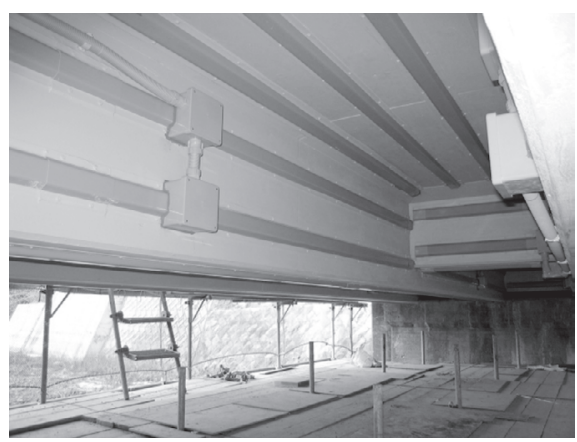

図 14 FRP トレイ型陽極による橋梁 $\mathrm{RC}$ 桁の電気防食

電源が不要なことから, 小規模施設や部分防食での期待 が高まっている。

\section{3 コンクリートの電気防食基準}

コンクリートの防食管理基準は, 電気防食時の電位と 無防食時の電位差（復極量）が $100 \mathrm{mV}$ 以上あれば良い とされている37),38). そもそもアルカリ環境で不動態化し ているため, 僅かにカソード分極させれば再不動態化す るためである.

電気防食時の電位には, 照合電極と鉄筋間に高抵抗の コンクリートが介在するため, 土壤よりも大きく IR ド 


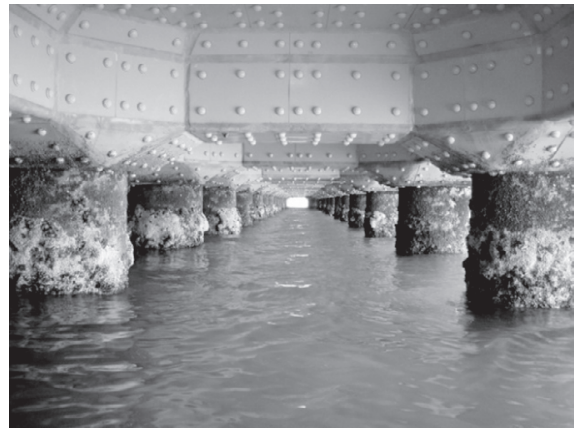

図 15 清水港における $\mathrm{Zn}$ 儀牲陽極板電気防食

ロップと呼ばれるオーム損が加算される。よって，カレ ントインタラプタ（電流遮断）法により IRを除去した インスタントオフ電位 $\left(E_{\mathrm{io}}\right)$ が計測されているが, 多く は電位差計の瞬時変化值を目読している，そこで，簡易 に測定できるインスタントオフ計が開発された ${ }^{39), 40)}$. こ れにより正確な復極量測定ができるようになった。

なお，コンクリートの電気防食は, 海水環境とは違っ た現象が起こる ${ }^{41)}$. 海水では電気防食を長期継続すると 鋼材の通電電位は卑化していくが，コンクリートでは貴 化していくことがある ${ }^{42)}$ 。これは表 1 に示すように, 海 水系では酸素欠乏による鋼材カソード分極抵抗増大の影 響による現象であるが，コンクリートでは陽極の分極抵 抗または極間抵抗の増大 $\left(E_{\mathrm{a}}+\mathrm{IR}\right.$ 線の増大 $)$ に起因す る現象である ${ }^{43)}$. 鋼材通電電位が貴化すると通電電流も 減少してしまい, 防食効果が低減しているように感じら れるが44), 鋼材自然電位が貴化し通電電流が低減して も，復極量が維持または増加する傾向が認められ，防食 効果は維持または改善することが多い44)。これは，表 2 に示すように，コンクリートでは電気防食による鋼材表 面のアルカリ生成反応により鋼材の再不動態化現象が起 きていることで説明される.さらに $\mathrm{Cl}^{-}$濃度は電気泳動 により鉄筋表面から減少していく傾向にある。これらは 環境改善効果と言われ，これを考慮した設計手法も提案 されている ${ }^{45)}$.

このように, コンクリートの持 つ優れた性質，すなわちアルカリ 固相環境であることを上手に活用 すれば，環境抵抗は相当高いもの の，僅かな電流で鋼材を防食する ことが可能となる.

中性液相環境の海水と同様にコ ンクリートの電気防食を制御した 場合，大きな電流を供給している にも関わらず，復極量が $100 \mathrm{mV}$ に到達しないばかりか, 外部電源 方式の陽極周囲の充填モルタルが 変質することもある。この変質は 下記に示すアノード反応の酸発生 によるもので, 大電流供給により 起こうる. 微弱な電流であればセ メントの持つ過飽和の $\mathrm{Ca}(\mathrm{OH})_{2}$ により中和されるので問題ない.

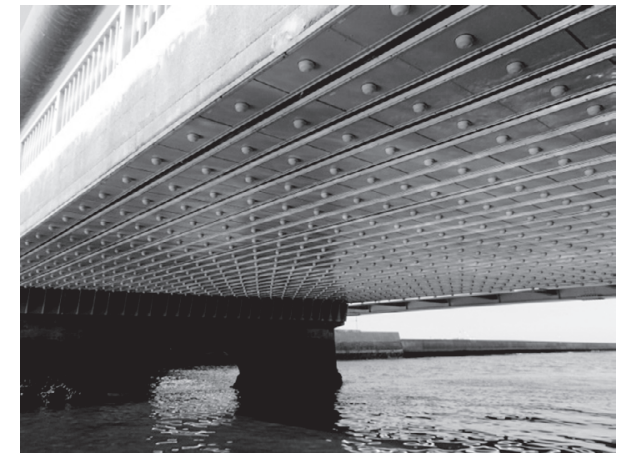

橋梁

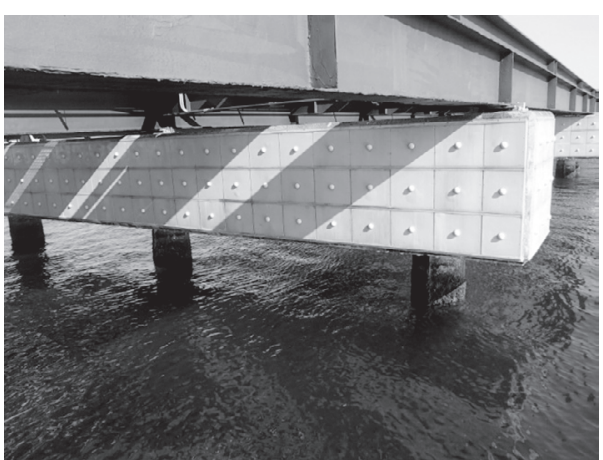

渡り栈橋横桁

図 $16 \quad \mathrm{Al}$ 犠牲陽極板電気防食

$$
\begin{aligned}
\text { アノード反応 }: & \left.\mathrm{H}_{2} \mathrm{O} \rightarrow 1 / 2 \mathrm{O}_{2}+2 \mathrm{H}^{+}+2 \mathrm{e}^{-} \text {(外電 }\right) \\
& \mathrm{Zn} \rightarrow \mathrm{Zn}^{2+}+2 \mathrm{e}^{-} \quad(\text { 流電 }) \\
& \left.2 / 3 \mathrm{Al} \rightarrow 2 / 3 \mathrm{Al}^{3+}+2 \mathrm{e}^{-} \text {(流電 }\right)
\end{aligned}
$$

カソード反応 : $\mathrm{H}_{2} \mathrm{O}+1 / 2 \mathrm{O}_{2}+2 \mathrm{e}^{-} \rightarrow 2 \mathrm{OH}^{-}$(外電. 流電)

これらのことを考えると，コンクリートの電気防食で は過度の通電は控えることが肝要である．外部電源方式 では定電圧電源, 適正な陽極配置や回路分割などを考慮 する必要がある．犠牲陽極方式は元来過剩通電の危険性 は小さいため, 意外にコンクリートの防食には適してい

表 1 環境条件の相違による電気防食状態の概念図

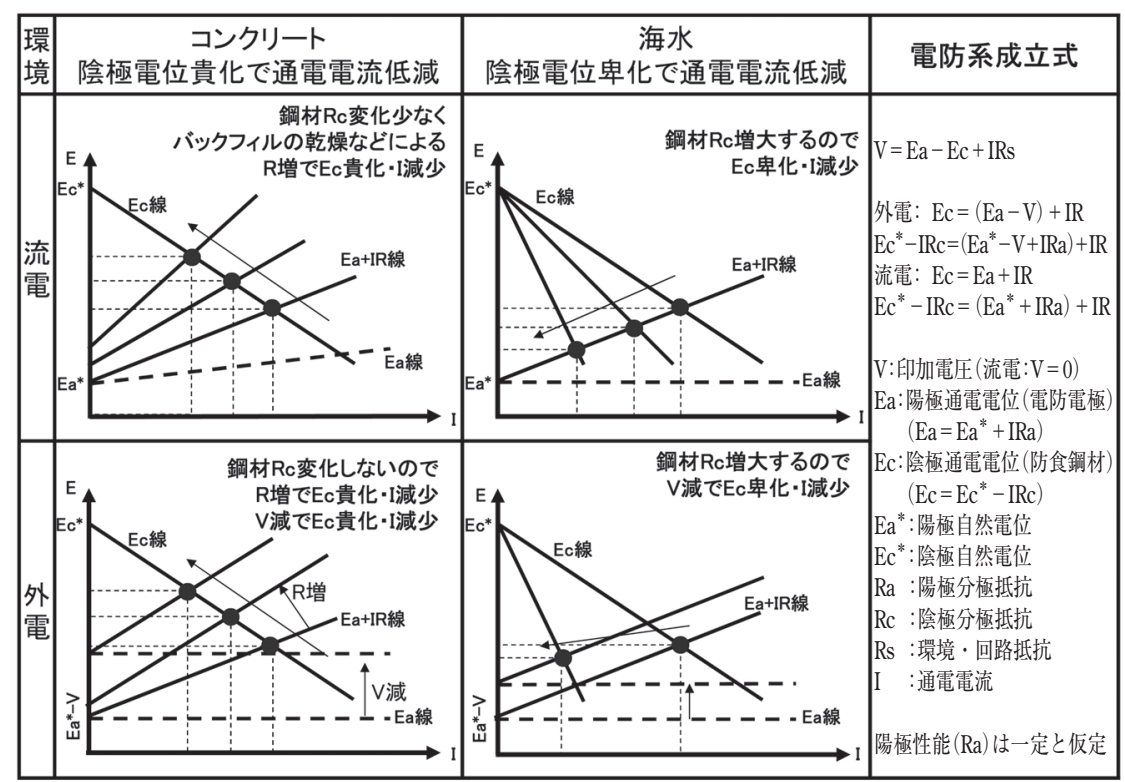


表 2 環境条件の相違による電気防食下の鋼材腐食概念困

\begin{tabular}{|l|l|}
\hline コンクリート & \\
\hline &
\end{tabular}

59th Jpn. Conf. Materials and Environments, p.253 (2012).

12）沿岸開発技術研究センター, 港湾鋼 構造物防食・補修マニュアル（改 訂版)，63 (1997)

13) N. Mochizuki, M. Iketani, Proc. 55th Jpn. Conf. Materials and Environments, C307 JSCE (2008).

14）沿岸技術研究センター, 港湾鋼構造 物防食・補修マニュアル, 86 (2009).

15) N. Mochizuki and M. Ikeya, Proc. JSCE Materials and Environments 2009, p.377, JSCE (2009).

16) H. Kobayashi, T. Yamaji, Y. Akira, $H$ Hamada, N. Mochizuki, K. Shimo, Zairyo-to-Kankyo, 62, 192 (2013)

17) H. Kobayashi, T. Yamaji, K. Yonamine, Y. Akira, H. Hamada, Proc. 60th Jpn. Conf. Materials and Environments, p.275, JSCE (2013)

18）腐食防食協会,危険物施設の鋼製地 下貯蔵タンク及び鋼製地下配管の 電気防食 (2006)

19) F. Kajiyama, Bosei Kanri (Rust Prev. Control), 51, 477 (2007).

20) T. Kitagawa, K. Haraga, Proc. JSCE

るとも思える。

今後は，これまでのコンクリート電気防食の実績デー 夕を吟味して適切な維持管理をしていく必要があり，そ うした研究報告も最近発表されている ${ }^{46)}$ 。コンクリート 施設の量は膨大であり，新たな工法やモニタリング，維 持管理法など，さらなる発展を期待する。

\section{6.おわりに}

電気防食と被覆防食について，防食対象の環境別に概 要を記載した。防食対象は社会を支える重要な土木構造 物や機械設備であることを改めて痛感した。これまで防 食対象鋼材，すなわち院極側の情報を主に測定評価する ことが多かったが，電気防食システムを適切に維持管理 する上では陽極側情報も重要である．計測機器や計算ソ フトが充実している現在，多量のデー夕を取得解析する ことは容易となってきた。これらの技術を活かし，電気 防食や被覆防食の更なる発展に努力していく所存であ る。

\section{参 考 文 献}

1) T. Kashiwagi, Zairyo-to-Kankyo, 58, 200 (2009)

2）沿岸技術研究センター, 港湾鋼構造物防食・補修マニュア ル, 59 (2009)

3）審良善和，山路徹，小林浩之，板倉新，高橋小夜佳，鈴木 大介，材料と環境 2011, B106（2011）.

4）町田勇太、志鶴真介, 吉田倫夫, 防錆管理, p161（2013）

5）志鶴真介，大野康彦，中村定好，石井達也，第 25 回防錆 防食技術発表大会予稿集，21（2005）.

6）曾根幸宏，山本郁雄，仲谷伸人，第 11 回防錆防食技術発 表大会講演予稿集，91（1991）。

7) M. Hattori, A. Nishikata and T. Tsuru, Zairyo-to-Kankyo, 60, p.15 (2011)

8) N. Yoneya, K. Amaya, Y. Akira, K. Tashiro and T. Iida, Zairyoto-Kankyo, 62, 11 (2013).

9) N. Yoneya, K. Amaya, Y. Akira, K. Tashiro, T. Iida, T. Yamaji, Zairyo-to-Kankyo, 62, 326 (2013).

10) Y. Akira, H. Kobayashi, T. Yamaji, M. Nemoto, N. Yoshida, Y Maezono, Proc. 57th Jpn. Conf. Materials and Environments, p.394, JSCE (2010).

11) Y. Akira, T. Yamaji, H. Kobayashi, Y. Watabe, S. Itakura, S Takahashi, N. Yoshida, Y. Maezono, H. Takayanagi, Proc.
Materials and Environments, 2012, p.293, JSCE (2012).

21） T. Wakabayashi, T. Kodama, N. Mochizuki, Proc. 58th Jpn. Conf. Materials and Environments, p.229, JSCE (2011).

22) T. Sunaba, T. Matsubara, Y. Kushima, T. Matsumoto, Y. Kuno, Y. Shinoda, N. Mochizuki, Proc. 60th Jpn. Conf. Materials and Environments, p.283, JSCE (2013).

23）南正信, $\mathrm{Jitsu} \cdot \mathrm{Ten}$ 実務と展望，263,30（2011）。

24）大庭忠彦，配管技術，644, $130 （ 2006 ）$

25）南正信，Jitsu·Ten 害務と展望，264, 33 (2011)

26) S. Moriya, Y. Sone, N. Mochizuki, Proc. 50th Jpn. Conf. Materials and Environments, b104 (2003).

27） http://www.chuden.co.jp/resource/corporeate/news_118 N11829.pdf

28) H. Yajima, Bosei Kanri (Rust Prev. Control) , 55, 16 (2011).

29）溝㴊利明, コンクリートの崩壊, PHP 新書 875 など

30）加納伸人, 望月紀保, 篠田吉央, 千葉丈夫, コンクリート 工学年次論文報告集, 10-2, 1091 (1988)。

31） 中村豊、池田辰男, 長田雅人, 善一章, 千葉丈夫, コンク リート工学別冊，29. No. 2, (1991)

32）加藤義史, 尼崎健一, 山崎茂, 加納伸人, 坂屋好彦, 宿里 伸也, 土木学会第 68 回年次学術講演会 V -194, 387 (2013).

33）又川兼雄, 田淵聡朗, 小林俊秋, 布田仁美, 土木学会第 64 回年次学術講演会 VI -390, 779 (2009).

34) http://www.umeshunkyo.or.jp/ronbun/h24_port abstracts/5.pdf

35) H. Fuda, Y. Shinoda, S. Otani, Y. Matsuda, Zairyo-to-Kankyo, 60, 487 (2011).

36）布田仁美, 加藤善史, 玉置祐史, 棚橋昭浩, 土木学会第 68 回年次学術講演会 V -196, 391 (2013)。

37）土木学会, 電気化学的防食工法設計施工指針（案), 91 (2001).

38) Y. Shinoda, N. Mochizuki, H. Nakauchi, T. Chiba, Proc. of Fushoku-Boshoku'88, p.165 (1988)

39) T. Kodama, Y. Shinoda, K. Tanaka, Zairyo-to-Kankyo, 59, 187 (2010)

40）田中一弘, 小玉俊明, 篠田吉央, コンクリート工学年次論 文集，33,1109（2011）。

41) N. Mochizuki, Zairyo-to-Kankyo, 59, 121 (2010).

42) T. Kodama, Zairyo-to-Kankyo, 61, 227 (2012).

43) Y. Shinoda, N. Mochizuki, S. Otani, H. Kobayashi, T. Wakabayashi and T. Takaku, SCMT3, M3-1, e188 (2013).

44）布田仁美，篠田吉央，松田芳範，コンクリート工学，49 [8] 17 (2011)

45) H. Kobayashi, Y. Akira, T. Yamaji, H. Hamada, T. Wakabayashi, N. Mochizuki, Zairyo-to-Kankyo, 62, 153 (2013).

46）布田仁美，松田芳範，篠田吉央，治田富雄，小城守，望月 紀保，第 1 回北陸橋梁保全会議 C-4（2013）.

(2014 年 1 月 9 日受理 $)$ 